\title{
As velas de Grin
}

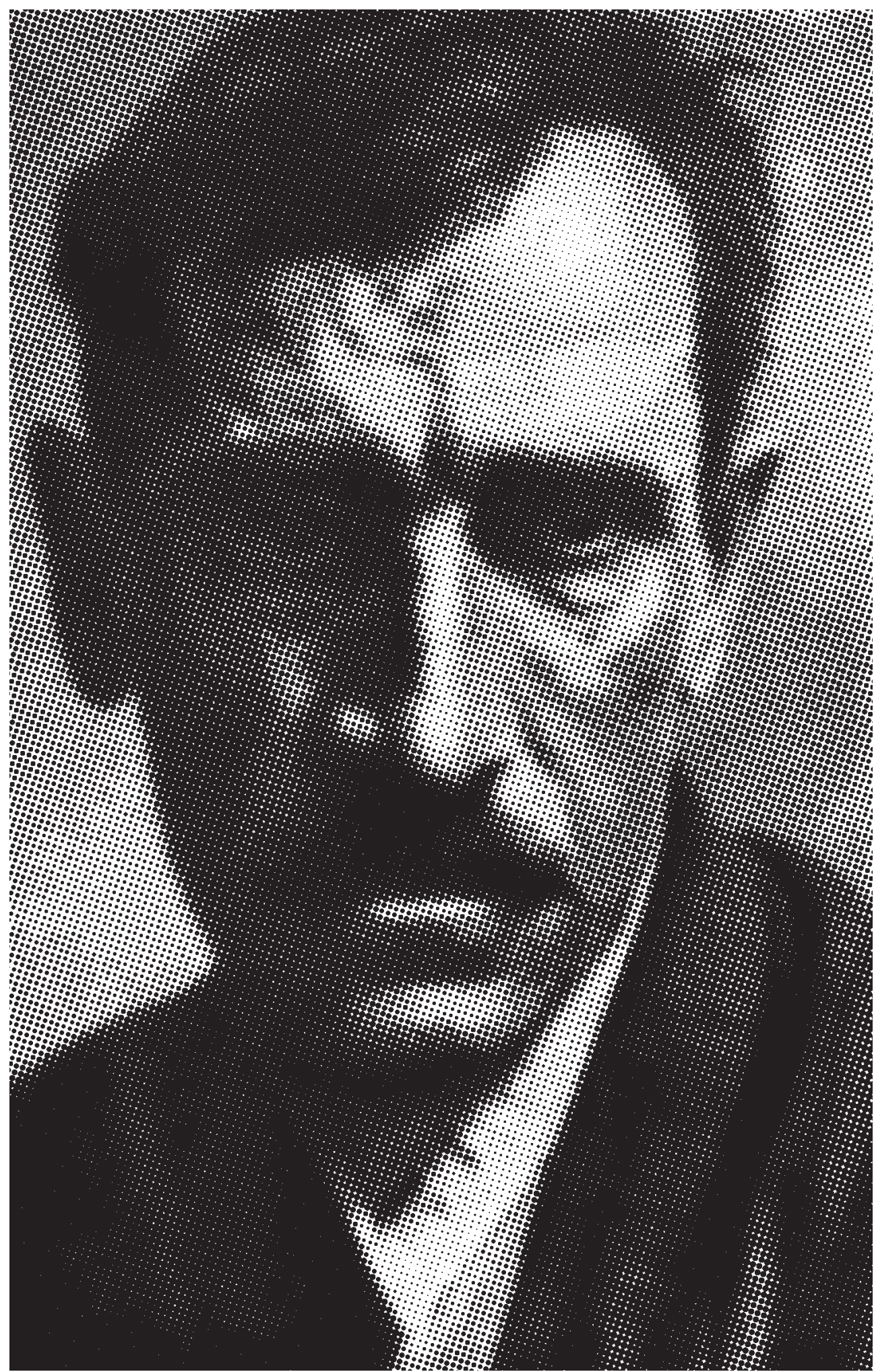




\section{NOÉ SILVA}

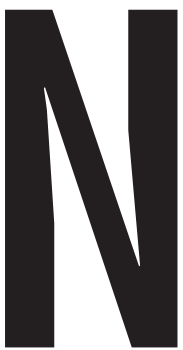

a literatura soviética, tão caracterizada pela diversidade de correntes e estilos, há uma figura absolutamente singular, Aleksandr Grin. Os seus primeiros leitores pensaram tratar-se de um ocidental traduzido em russo; ele, no entanto, saíra uma única vez do país e, ainda assim, por apenas alguns dias, passados praticamente a bordo de um navio, em uma viagem de Odessa a Alexandria.

Os seus contos, novelas e romances inusitados suscitavam estranheza e, malgrado o silêncio despectivo da crítica, conquistavam crescente popularidade, em uma época de, por exemplo, autores voltados para heróis e acontecimentos da Revolução de Outubro (Dmítri Fúrmanov, Aleksiéi Serafimóvitch e Nikolai Ostróvski), poetas de destino tão trágico quanto brilhante (Serguiéi Essiénin e Vladímir Maiakóvski), satíricos ferinos e geniais (Mikhail Bulgákov, Iliá Ilf e Evguiéni Petrov), e de magníficos realistas, como Andriéi Platónov.

Grin não foi embaixador do exotismo em meio aos seus pares eslavos, pois o seu processo criador e a habilidade em encadear o fantástico com o real vinham dos contos populares russos, do Nikolai Gógol de Nariz e Retrato, de Fiódor Dostoiévski e das histórias de Nikolai Wagner, mais conhecido como Kot-Murlyka (GatoRonronador).

O ar de sonho e eternidade, através do qual via o mundo, desprendia-se da terra, em que viviam e trabalhavam ele e os seus leitores. Criou o seu próprio mundo, a "Grinlândia" (termo cunhado pelo crítico K. Zelínski), com cidades portuárias barulhentas e cheias de cantos e aromas, de nomes exóticos (Zurbagan, Liss, GuelGuiu, Gherton, etc.), banhadas por mares embaladores de corações intérritos e jovens.
O mar de Grin tem pouco do meio áspero, concreto, da dura vida de fome e privações dos pescadores, das varinas, das praias de naus impregnadas do cheiro de sal e peixe, de crianças malvestidas e famintas (que se encontra, por exemplo, em Os Pescadores de Raul Brandão e, com certo grau de poetização, em Os Lestrigões de Aleksandr Kuprin); na poética do escritor, ele é a expressão simbólica da grandiosidade e da infinitude do mundo espiritual do homem.

Era irresistível o encanto de fadas vestidas com a roupa das pessoas comuns, a simpatia dos seus cavalheiros, a nobreza e alegria de viver dos seus pobretões e aventureiros, quase sempre marujos. O fascínio de Grin aumentava com as fábulas difundidas sobre ele, como conseguir cravar uma seta em uma maçã colocada a mais de cem metros de distância e ter de caçar codornizes com arco e flecha, nos arredores de Feodóssia, para não morrer de fome... Além, também, de patranhas maldosas, como haver ele assassinado um inglês, capitão de navio, e roubado os seus manuscritos.

O artista Grin transportou para o território livre e heróico do oceano da sua imaginação, para longe da realidade prosaica e intolerável, o homem Griniévski, lenhador, garimpeiro, estivador, escrevedor de cartas para fregueses analfabetos de botequins e hóspede de albergues. Fez do sonho e do louvor à vida a quinta-essência da sua obra, composta, toda ela, de luz, ventos favoráveis e ervas floridas, com personagens de nomes estranhos (ora anglo-saxões, ora não pertencentes a idioma nenhum) aos ouvidos russos, umas sonhadoras, outras rudes e temperamentais, capazes de correr sobre as ondas e levitar.

$$
* * *
$$

Aleksandr Stepánovitch Griniévski nasceu em 1880, em Slobódski, na região de Viatka, a uns oitocentos quilômetros a nordeste de Moscou. Um ano depois, a sua família mudou-se para tal cidade, então parte já da história do país por causa dos seus cárceres e centros de triagem de prisio-
NOÉ SILVA é professor de Literatura Russa da FFLCH-USP. 
Documento, na Rússia czarista que apontava a pessoa como indivíduo politicamente suspeito e the vedava o acesso ao ensino e ao serviço públicos.

2 A Polônia era parte do império russo; tornou-se país soberano em 1918.

3 Partido surgido, em 1902, do grupos populistas do século XIX contrários aos regime czarista lalguns optaram pela propaganda políitica, outros, como a Naródnaia vólia - A Vontade do Povo - dedicavam-se à eliminação física dos representantes do poder). Defendia a entrega das terras dos latifundiá rios ao campesinato, com a manutenção, por outro lado, da propriedade privada sobre os meios de produção, e empregava ações terroristas conspiratórias. Tinha muitos simpatizantes entre os soldados, camponeses, na sua maioria. Assim como os mencheviques os socialistas-revolucionário não achavam a Rússia preparada para a revolução social depois de Outubro, opuseramse aos bolcheviques.

4 Grin publicou, em 1932, uma Novela Autobiográfica, a sua vida romanceada, de que se omitem períodos importantes.

5 Em 1914, com o início da Primeira Guerra Mundial, que opôs a Rússia e a Alemanha, a capital trocara a sua denominação germânica, São Peters burgo, pelo equivalente russo, Petrogrado, ou seja, "a cidade de Pedro"; recebeu o nome le ningrado após a morte de lênin, em 1924

6 Em um de seus retornos do exterior, aonde fora tratar-se de tuberculose, Górki, pessod muito acatada pelos bolche viques, intercedeu em favor de Grin. Foi nesse período que Grin escreveu as suas duas meIhores obras: a novela Alye Parussá (Velas Rubras), o seu verdadeiro bilhete de visita, romance Blistáiuchtchi Mir (Mundo Brilhante), ambos vin dos à luz em 1923 neiros. Menino sorumbático, não estudou regularmente, pelo gênio travesso, que lhe traria o "bilhete de lobo" (1); para além disso, batia-lhe muito o pai alcoólatra, um nobre polaco desterrado para ali depois do levante de Varsóvia contra o domínio russo, em 1863 (2). Encontrava, nos livros, o que não tinha na vida. Fugiu de casa, tentou encontrar ouro na Sibéria e trabalhar como marinheiro no Mar Cáspio; para ficar longe dos parentes, alistou-se no exército. Desertou um ano depois, atraído para o Partido Socialista Revolucionário (3), e desenvolveu intensa atividade clandestina em Kiev, Odessa, Níjni Nóvgorod, Simbirsk e outros sítios; foi preso no outono de 1903, no porto de Sebástopol.

$\mathrm{Na}$ infância, sobejaram motivos para fazer Grin não gostar das pessoas e da vida. Ele, que sonhava com viagens ao redor do mundo, com uma existência variada e interessante, passava fome. No fundo de uma cela da prisão de Sebástopol, deu vazão à imaginação e criou terras extraordinárias, urbes encantadoras, defensas à dura realidade soviética.

Há uma lacuna na sua vida após a soltura, ocorrida no fim de outubro de 1905. Sabe-se apenas de outra prisão e desterro para a Sibéria. No caminho, ele escapuliu, conseguindo chegar a Viatka; o pai roubou os documentos do filho morto de um sacristão, e foi com o sobrenome Malguínov que Grin partiu para São Petersburgo e até assinou os dois contos de estréia, destinados à propaganda entre os soldados e publicados no jornal Birjevie Viédomosti (Boletins da Bolsa).

A sua primeira coletânea de relatos (1908), escritos à moda realista, inspirouse na sua vida de subversivo (a eliminação de agentes infiltrados, o cárcere, as conspirações e assim por diante). Ele tinha um cabedal de experiências capaz de render páginas de uma veemência humana comparável à da prosa autobiográfica de Maksim Górki (Infância, Ganhando o Meu Pão, As Minhas Universidades e Pela Rússia, ciclo de contos sobre as suas andanças pelo país), mas refugiou-se definitivamente no mundo da fantasia(4).
Foi preso pela terceira vez, embora não pertencesse já àquele partido, e, um ano depois, exilado para a região de Arkhánguelsk, no inóspito Norte da parte européia da Rússia, de onde pôde voltar para a capital somente em 1912.

Vivia na Finlândia, quando da Revolução de Fevereiro, em 1917. Foi convocado para o Exército, depois da Revolução de Outubro, e mandado para a Carélia, mas adoeceu gravemente de tifo. Em Petrogrado (5), faminto e ainda enfermo, procurou o autor de Mãe; este, um dos seus admiradores declarados, conseguiu-lhe um quarto em um apartamento comunitário para escritores e uma ração diária de comida (6).

Grin morreu em 1932, de cancro, na extrema pobreza, na cidade de Stáry Krym, Criméia, hoje parte da Ucrânia.

$$
* * *
$$

A literatura apresenta muitos exemplos de evolução do romantismo para o realismo; Grin infringiu essa quase norma do desenvolvimento da personalidade dos escritores. Uma das causas desse raro fenômeno foi a forte impressão das leituras nele: "O que lia nos livros, ainda que a fantasia mais barata, foi sempre para mim a realidade aflitivamente desejada".

O método criador de Grin formou-se muito antes da revolução socialista e sofreu a influência das tendências neo-românticas do processo literário na Rússia do começo do século XX, presentes, de uma forma ou de outra, no simbolismo e no impressionismo, no acmeísmo e no expressionismo. Simultaneamente, a sua prosa combinava, entre outras coisas, elementos do conto ocidental, efeitos sentimentais ao gosto do grande público, um apurado psicologismo e o apego a enredos cheios de lances. Ao entrar no período soviético, esse programa estético, delineado com habilidade e tento, apesar da variedade de fontes, não podia já ser revisto. À luz da auréola romântica dos escritos sobre a "Grinlândia" empalideciam os seus trabalhos iniciais.

No entanto, em tudo o que se publicava sobre Grin na União Soviética, tratavam- 
no como mero imitador dos mestres europeus e estadunidenses do gênero de aventuras (Júlio Verne, Robert Louis Stevenson, Edgar Alan Poe, Rudyard Kipling, Fenimore Cooper, Jack London e outros). Exprobravam-lhe a desconformidade com o espírito da época e o "cosmopolitismo"e reconheciam-lhe somente habilidade no enredo. Antipatizavam até com o seu nome, achando que o escolhera para parecer estrangeiro (Grin, abreviação do sobrenome, constituía meramente um apodo dos tempos de criança). Escusa dizer que não se reeditavam os seus livros, declarados nocivos à juventude e retirados das bibliotecas.

A reabilitação do escritor começou com a relativa liberalização do regime soviético, o "desgelo" de Nikita Khruchtchov, após a morte de Ióssif Stálin (1953), e para ela contribuíram os esforços de Konstantin Paustóvski e um artigo de Mark Chtcheglov (7).

Grin foi vítima dos críticos e dos generais da literatura, do preconceito do senso prático, que fazia essas pessoas confundirem o que está perto com o real e desprezar o que é distante e eterno, o que determina as coisas próximas e efêmeras e prepara-as.

Aos imbuídos de tal preconceito não agradavam as asas soltas da imaginação, que, no caso dele, eram as velas pandas de navios.

O seu primeiro livro de criança foi uma edição ilustrada de As Viagens de Gulliver, de Jonathan Swift, e a primeira palavra soletrada e decorada - mó-rie (mar). As ondas entraram a embalar os pensamentos do menino arredio e rebelde de uma cidade provinciana russa, e o escritor procurou legitimar como real e alcançável o mundo da fantasia juvenil, "o mundo escancarado à loucura dos ventos", pelas palavras de outro romântico, o poeta Eduard Bagrítski, de Odessa.

As obras de Grin celebram o ímpeto heróico, a audácia fecunda, a atitude criadora. São retalhos iluminados de uma sinfonia à esperança e ao inesperado. Trazem uma exortação a que arejemos os nossos dias na atmosfera do possível e, entre os cuidados e obrigações, deixemos a respira- ção encantada dos nossos anelos vestir uma roupa vistosa nas coisas triviais.

Lembremos, foi uma marinha que, na mais famosa daquelas, fez de um menino o futuro capitão do magnífico barco Sekriét (Segredo). Com música e cantos de marinheiros embriagados de vinho português, esse galeote de velas de seda rubra alvoroça um povoado de pessoas rudes, que desprezam quem aspira à cordialidade e às puras alegrias da alma, em meio à vulgaridade e à brutalidade do dia-a-dia. Ensina-se que milagres não são coisas de santos, mas de mãos operosas, mentes inspiradas e corações apaixonados. E, quem sabe, para quantos as histórias de Grin não foram, e haverão ainda de ser, como o tal quadro para o rapazola impressionável, a "palavra necessária, na palestra da alma com a vida, sem a qual é difícil compreender a si próprio"?...

\section{DUAS HISTÓRIAS DE GRIN}

\section{A lâmpada verde}

\section{I}

Em Londres, em 1920, em uma noite de inverno, na esquina de uma ruazinha com a Picadillus, pararam dois cavalheiros bem vestidos, de meia-idade. Haviam acabado de deixar um restaurante caro. Jantaram, beberam vinho e gracejaram com as artistas do Teatro Drewreleen.

Naquele momento, a sua atenção fora atraída por um homem malvestido, de uns vinte e cinco anos, estirado no chão, ao pé do qual começava a juntar-se uma multidão.

- Stilton!-disse com asco o cavalheiro gordo ao seu companheiro, ao ver este inclinar-se sobre o homem e pôr-se a examinálo. - Palavra de honra, não vale a pena preocupar-se tanto com esse animal morto. Se não morreu, então está bêbedo.

- Eu estou com fome... e estou vivo murmurou o infeliz, soerguendo-se para olhar para o pensativo Stilton. - Isto foi um desmaio.
7 Konstantin Paustóvski, grande escritor romântico e leitor de Gin desde a infância, dedcouthe muitas páginas l"pensei nele e escrevi sobre ele consciente de que the pagava um tributo pequeno demais pelo presente generoso, que deixara tão desinteressadamente a todos os sonhadores poetas") e conseguiu a publcação de obras suas e o paga mento dos direitos autorais sua viúva pelas editoras. No magnífico artigo "Korab Aleksándra Grína" |"As Naus de Aleksandr Grin"), o crítico Mark Chtcheglov, que morre ainda muito jovem, fala dos aspectos principais da obra de Grin e faz uma defesa apaixonada do seu método criador.

8 Tradução de Noé Silva. 
- Raemer! - disse Stilton. - Eis cá uma oportunidade para graça. Tive uma idéia interessante. Estou farto das distrações de sempre, e brincar de verdade só é possível de uma maneira: transformar pessoas em brinquedos.

Essas palavras foram ditas em voz baixa, de modo que as não ouviu o homem, agora encostado a uma grade.

Raemer, que não queria saber de nada, deu de ombros com desprezo, despediu-se de Stilton e foi matar o tempo ao seu clube, ao passo que Stilton, com a aprovação da multidão e a ajuda de um polícia, levou o desvalido homem para um $c a b$ (9).

O carro rumou para uma das tabernas da High Street.

O vagabundo chamava-se John Ivy. Chegara da Irlanda em busca de trabalho. Era órfão, criado pela família de um guardaflorestal. Em matéria de instrução, não fora além da escola primária. Quando tinha quinze anos, morreu o seu pai adotivo, e os filhos deste dispersaram-se pelo mundo, cada um para umlado-América, Gales do Sul e outras partes da Europa. Ivy trabalhou algum tempo em uma propriedade rural. Depois, teve de experimentar o trabalho de mineiro de carvão, marinheiro, empregado de taberna $\mathrm{e}$, aos vinte e dois anos, quase sucumbiu a uma pneumonia; ao receber alta do hospital, resolveu tentar a sorte em Londres. A concorrência e o desemprego, no entanto, mostraram-lhe depressa que encontrar emprego não era assim tão fácil. Ele dormia em parques e desembarcadouros, passava fome, definhou e foi, como vimos, levantado do chão por Stilton, proprietário de armazéns de comércio na City.

Stilton, aos quarenta anos, conhecera tudo o que o dinheiro podia dar a um homem solteiro, livre de preocupações com abrigo e comida. O seu patrimônio chegava a vinte milhões de libras. As suas intenções em relação a Ivy eram uma rematada estupidez, mas ele orgulhava-se muito da sua inventividade, pois considerava-se uma pessoa de imaginação fértil e fantasia refinada.

Quando Ivy bebeu vinho, fartou-se de comida e contou a sua história, Stilton declarou:
- Quero fazer-lhe uma proposta, que fará os seus olhos brilharem. Escute: doulhe dez libras sob a condição de que ainda amanhã alugará um quarto em uma das ruas centrais, no segundo andar, com uma janela para a rua. Todas as noites, pontualmente, das cinco horas à meia-noite, no peitoril de uma janela, sempre a mesma, deverá arder uma lâmpada, coberta por um quebra-luz verde. Nesse horário estipulado para ela estar acesa, o senhor não sairá de casa, não receberá visitas nem falará a ninguém. Em suma, a tarefa não é difícil, e, se concordar em executá-la, eu lhe enviarei dez libras por mês. O meu nome lhe permanecerá ignoto.

- Se não está a mangar - respondeu Ivy, admiradíssimo da proposta -, eu estou disposto a esquecer até o meu próprio nome. Mas, por favor, diga-me: por quanto tempo será esta minha prosperidade?

- Isso não se sabe. Talvez um ano, talvez a vida inteira.

- Melhor ainda. Mas atrevo-me a perguntar, para que precisa da tal iluminação verde?

-É segredo! - respondeu Stilton. - Um grande segredo! A lâmpada será um sinal para pessoas e coisas, de que jamais saberá.

- Percebo. Isto é, não estou a perceber nada. Muito bem, mande daí o dinheiro e saiba que amanhã ainda, no endereço indicado por mim, John Ivy acenderá uma lâmpada à janela!

Assim se concluiu o estranho acordo, após o qual o vagabundo e o milionário se separaram, plenamente satisfeitos um com o outro.

Na despedida, disse Stilton:

- Escreva-me para a posta-restante, assim: "3-33-6". Tenha em vista que em um dia qualquer, daqui a um mês, talvez, ou um ano, em suma, quando menos esperar, visitá-lo-ão pessoas, que o tornarão uma pessoa abastada. Por que isso e como, eu não tenho o direito de explicar-lhe. Mas tal acontecerá...

- Com os diabos! - murmurou Ivy, a olhar para o $c a b$, que se afastava com Stilton, enquanto rolava a nota de dez libras entre os dedos. - Ou esse homem endoideceu, ou 
eu sou um grande felizardo! Oferecer-me um monte de felicidade só para eu gastar meio litro de querosene por dia!

Na noite do dia seguinte, uma janela do segundo andar do sombrio prédio no 52 da River Street iluminou-se de suave luz verde. A lâmpada fora encostada ao caixilho.

Dois passantes olharam algum tempo para a janela verde, da outra calçada; depois, disse Stilton:

- Pois aí está, meu caríssimo Raemer, quando sentir tédio, venha cá e sorria. Atrás daquela janela, estará sentado um tolo. Um tolo comprado a preço baixo, a prestações, por muito tempo. Tornar-seá um beberrão de tédio ou ficará doido... mas estará sempre à espera, sem saber do quê. Pois lá está ele!

Realmente, uma figura escura, com a testa apoiada no vidro, olhava para a meiaescuridão da rua, como que a perguntar-se: “Quem estará lá? Pelo que devo esperar? Quem virá?".

- Você também é um tolo, meu caro disse Raemer, levando o companheiro pelo braço ao automóvel. - Que há de engraçado nessa brincadeira?

- O brinquedo... o brinquedo, feito de uma pessoa viva - disse Stilton -, é o prato mais doce!

\section{II}

Em 1928, um hospital de pobres, dos arrabaldes de Londres, encheu-se dos gritos selvagens de dor de um velho recémtrazido, pessoa imunda, de roupa esfarrapada e rosto chupado. Ele quebrara a perna, ao tropeçar em uma escada de serviço de um antro escuro.

Levaram-no à seção cirúrgica. $\mathrm{O}$ caso era grave, já que a fratura do osso provocara rompimento de vasos.

Do processo inflamatório dos tecidos o cirurgião, que examinava o infeliz, concluiu que era necessária uma operação. Ela foi realizada imediatamente, após o que o velho enfraquecido foi colocado em uma maca; ele logo adormeceu e, ao despertar, viu diante de si o mesmo médico, que lhe amputara a perna direita.
- Quis o destino que nos encontrássemos desta maneira! - disse o médico, um homem sério, alto, de olhar triste. - Não me reconhece, mister Stilton? Eu sou John Ivy, que o senhor encarregou de vigiar todos os dias o caminhar das horas, ao pé de uma lâmpada verde. Eu o reconheci à primeira vista.

-Com mil diabos! - murmurou, a olhálo atentamente, Stilton. - Que aconteceu? Será possível?

- Sim. Que fez mudar tão drasticamente o seu modo de vida?

- Eu fali... várias perdas grandes... pânico na Bolsa de Valores... Faz três anos que me tornei mendigo. E o senhor?

- Eu acendi a lâmpada durante vários anos - sorriu Ivy -, e comecei a ler tudo o que me caía nas mãos, no início, com tédio, depois, com enlevo. Certa vez, abri uma velha anatomia esquecida na estante do quarto alugado por mim, e fiquei impressionado. Abriu-se diante de mim o fascinante mundo dos mistérios do corpo humano. Passei a noite debruçado sobre o livro, embriagado com ele. De manhã, fui à biblioteca e perguntei: “Que é preciso estudar para ser médico?". A resposta foi em tom de troça: "Estude Matemática, Geometria, Botânica, Zoologia, Morfologia, Biologia, Farmacologia, Latim, etc.". Mas eu continuei obstinadamente com as minhas perguntas, e anotei tudo. A essa época, fazia já dois anos que acendia a lâmpada, e uma noite, quando voltava para casa (eu não achava necessário, como antes, ficar sete horas em casa, sem sair), vi um homem de cartola, que olhava para a minha janela verde nem bem com enfado nem bem com desprezo. "Ivy é o tolo clássico! - murmurou ele, sem notar-me. - Espera pelas belas coisas prometidas... pois é, ele, ao menos, tem esperanças, ao passo que eu... eu estou quase arruinado!" - Aquele homem era o senhor. Acrescentou: "Brincadeira idiota. Não devia desperdiçar dinheiro". Eu comprara livros em quantidade suficiente para estudar, estudar e estudar, acontecesse o que acontecesse. Eu por pouco não lhe bati naquela noite, mas lembrei-me de que era graças à sua generosidade escarninha que 
eu podia tornar-me uma pessoa instruída.

- E depois?

-Depois? Estábem. Se é forte o desejo, a sua realização não tarda. No meu andar, morava um estudante; ele interessou-se por mim e ajudou-me, mais ou menos um ano e meio depois, a prestar os exames de ingresso na Escola de Medicina. Como vê, revelei-me uma pessoa capaz...

Os dois ficaram em silêncio.

- Foi há muito tempo a minha última ida à River Street para ver a sua janela disse Stilton, comovido com o relato de Ivy -, foi há muito, muito tempo... Mas parece-me que ainda hoje, ali, arde uma lâmpada verde, a iluminar a escuridão da noite... Perdoe-me.

Ivy tirou o relógio do bolso.

- Dez horas. Hora de o senhor dormir. Talvez receba alta em três semanas. Então, procure-me, que o empregarei no nosso ambulatório: o trabalho consiste em registrar os doentes que chegam. Agora, quando for descer uma escada no escuro, acenda... ao menos um palito de fósforo.

\section{0 comandante do porto}

\section{$\mathbf{I}$}

Quando anoiteceu, pelo portaló ricamente iluminado do cargueiro "Record" subiu o Comandante. Era um homem de uns setenta e dois anos, aprumado, de compleição débil, muito popular no porto. A sua carinha enrugada, como uma pêra seca, estava esmeradamente escanhoada. As suíças encanecidas ressaltavam do rosto como as barbatanas de um peixe; de sob as palas encanecidas das sobrancelhas, brilhavam dois olhinhos azuis, em um sorriso agradável. O boné de marinheiro, o casaquinho castanho, as calças brancas, a gravata azul e a bengala barata do Comandante, à luz forte da lanterna elétrica, apareciam em toda a sua miséria, da qual não os conseguiria livrar nem o mais esmerado conserto. As botas, que haviam já rebentado vinte e duas vezes, haviam sido remendadas, o mesmo número de vezes, com linha ou reforçadas com pedaços de arame. Do bolso de cima do casaco apontava um pedaço de seda colorida, bem pregado a ele.

Depois de ajeitar cuidadosamente o colarinho e, em seguida, encolher os ombros para aliviar a obstinação dos suspensórios, o velhote parou diante do marujo de quarto e abriu abruptamente os braços, com a cabeça inclinada de lado.

- Tom Laston! - exclamou o Comandante, com voz alegre, tremida. - Eu bem sabia que tornaria a vê-lo a bordo deste lindo navio, perdido em sonhos com a sua querida Betsy, que está... tão longe. Raios e trovões! A viagem está a correr bem, eu espero.

- Kutgay! - gritou Laston para a distância.-Chegou o Comandante. Que faço dele?

- Dá-lhe um pescoção! - voou a dura resposta.

O olhar do velhinho expressou um pedido, perplexidade, brejeirice. A sua bengalinha subiu e desceu, como a cauda de um cão, quando este tenta descobrir o estado de humor do dono.

- Pois bem, lá vai um pescoção nele, imediatamente! - respondeu-lhe Laston, com palmadas carinhosas no ombro do velho, que o fizeram acocorar-se, como se ele fosse dobradiço. - Acho que quererás cumprimentá-lo, Kutgay. Não temas, Comandante, Kutgay está a brincar.

-Longe de brincadeiras! - disse Kutgay, o fogueiro chefe, homem ossudo de ombros largos, abeirando-se dele. - É só aparecermos em Guerton, que já lá vem esse Comandante, sem falta. Até já estamos fartos. Deverias ir para casa dormir, velho.

- Eu acabo de descer do "Abraham Rapp" - pôs-se o Comandante a balbuciar, na tentativa de não ouvir as desagradáveis palavras do fogueiro. - Lá, está tudo em ordem. Fizeram boa viagem, o "Rapp" parte ao amanhecer. Bebi café, joguei damas com o mestre Tolby. Pessoa magnífica! Como vai, Kutgay? Tudo em ordem, espero. E a sua honorável família?

- Fuma - disse Kutgay, dando ao velho um cigarro preto. - Segura-o bem com a pata, senão cairá. 
- Ah, eis o senhor capitão! - exclamou o Comandante, dando um puxão vivo ao casaquinho e correndo para o capitão, que ia com a esposa ao teatro da cidade. - Boa noite, senhor capitão! Boa noite, minha infinitamente honorável e... hum... A noite está estão boa, que dá vontade de passear pela esplanada, a escutar uma música bem bonita. Como vai? Está tudo em ordem? Espero que sim. Não enfrentaram nenhuma procela na viagem? E a saúde... da melhor maneira possível?

- Ora, mas é o senhor, Tils! - disse, parando, o capitão Henry Galton, homem alto de uns trinta e cinco anos, de rosto grande e curtido pelos ventos. - Continua firme... Muito bem! Prazer em vê-lo! Nós, porém, estamos com pressa, assim que tome este dólar e vá lá para a cozinha, fazer companhia ao Butler, ali poderá conversar. Desejo-lhe tudo de bom. Mary, este é o Comandante.

- Então é o senhor? - sorriu a jovem mulher. - O "Comandante do porto"? Eu ouvi falar do senhor.

- Todos me conhecem! - pôs-se a rir Tils, com o cigarro em uma mão e o dólar e a bengala na outra. - Os marinheiros são um grande povo, e as nossas simpatias, espero, são mútuas. Eu, devo dizer, adoro marinheiros. O convés dos navios atrai-me como... como... como...

Sem esperar para ouvir o resto, o capitão levou a esposa para a margem, enquanto Tils, seguindo-os com o olhar, de chapéu respeitosamente um pouco levantado, concluiu, dirigindo-se a Laston:

- Que bravo, este vosso capitão! Um verdadeiro rapaz das procelas! Da cabeça aos pés.

Aqui é preciso esclarecer que o Comandante (tal era o seu apodo) era conhecido definitivamente por todos, da última taberna até ao escritório da Aduana. Tils trabalhara a vida inteira como escrevente, no armazém de uma grande companhia privada, até ser, finalmente, despedido por razões decorrentes da sua provecta idade. Desde então, era sustentado por uma irmã viúva e sem filhos, Rebecca Bartels, em cuja casa vivia.
Tils fora impedido de tornar-se marinheiro pela epilepsia, cujos ataques desapareceram, com a velhice, mas Tils permanecera um homem do mar apenas na imaginação. De manhã, a irmã enfiava-lhe no bolso do casaquinho um grande sanduíche, dava-lhe dez cents para gastos ao seu livrearbítrio masculino, e, a dar voltas à bengala, o Comandante começava a ronda do porto. Não tinha ele nenhum interesse cúpido, a sua atração por marinheiros e barcos vinha da infância, do dia em que, ainda nos braços da mãe, estendera as mãozinhas para a visão de velas, que descia pela janela azul do mar.

A fumar o cigarro com a mão tremente e encarquilhada, o Comandante dirigiu-se com passinhos regulares para a cozinha, onde, ao ver as pestanas e suíças, o cozinheiro desfez-se em gargalhadas.

- Eu sentia que aparecerias, Tils! - conseguiu ele dizer, por fim, empurrando um banco para o Comandante e dando-lhe café de um bule. - Onde estavas? Não notaste, decerto, o "Stella", ele ancorou atrás do cais de petróleo, em frente da usina. Ali, agora, estão precisamente a jogar cartas e a beber.

- Não imediatamente, não imediatamente, honorável Peter Butler-respondeu Tils, depois de um suspiro, e, achegando o banco à mesa, sentou-se, com as mãos entrelaçadas no gancho da bengala. - Como está a sua honorável saúde? Foi boa a viagem? A sua mui honorável esposa, eu espero, aguarda tranqüilamente o seu retorno, não? Hum... Eu estive no "Stella". Então, não haviam ainda começado a jogar, mas apenas mandado o segundo imediato comprar um baralho. Pois! Mas eu, sabe, fui-me logo porque ali há duas pessoas que me tratam... assim, de modo não amistoso. Elas disseram que eu sou uma gralha cinzenta, daquelas velhas e impertinentes, e que... Naturalmente, eu fiquei magoado e não pude falar-lhes do meu carinho por tudo... pelos bravos marinheiros... pelo convés... Mas ele me acompanha sempre, e o senhor sabe...

Tils, entristecido, soltou um soluço. Butler correu a um armarinho e depôs com um golpe na mesa uma garrafinha de licor de ananás. 
- Um velho lobo do mar como tu deve tomar um copinho - disse Butler. - Certo? Bebamos e esqueçamos esses biltres. À tua saúde! À minha saúde! Eia! Hop!

Deitando meio cálice da bebida na boca carnuda, Butler secou o lábio inferior com o polegar e olhou fixamente para Tils, que filtrava lentamente o seu cálice. Ao acabar, Tils mexeu os lábios como se quisesse dizer “am”. Derrubou algumas lágrimas, assoouse e pôs-se a chupar o cigarro apagado.

- Mais?

- Agradeço-lhe. Depois, talvez. Raios e trovões! O "Stella” é um bom barco, muito bom - foi dizendo Tils, e a cada palavra balançava a cabeça. - Lançaram-no ao mar em 1901. Charley não serve já no "Macaco Urrador", eu o vi ontem, no hotel do Marley. "Descansarei, diz ele. Sabe o que é - diz ele -, a companhia precisa acertar as contas comigo, não me pagaram o total dos prêmios." Estive hoje no "Touro Negro", a ver como iam as coisas por ali. Tudo em ordem. Rumper transferiu a cervejaria para outra esquina, a casa anterior foi vendida e será transformada em loja. Watson não consegue de modo nenhum reformar-se, que desgraça! Está a beber, raios me partam, está a beber feio, como um camelo ou uma serpente marinha. Dá gosto ver. Pega uma caneca, olha para ela. "Nas Filipinas - diz Watson -, pois, diz ele, houve fatos memoráveis. $\mathrm{Na}$ Jamaica, diz ele, muito bom." O "Royal Star" afundou. Dizem por cáque foi apanhado por um tufão. Canhões e pelouros! Conheceu Simon Lacray? O pirata? Simon Lacray era pirata, ele pagou-me uns tragos após... um trabalhinho. Pois bem, lá disse ele: “Não teriam afundado o 'Mossa', se não tivessem tido ajuda do próprio diabo”. E aí começou a praguejar de tal maneira, que todos até ficaram pensativos. Era um belo homem, esse Lacray, pode crer. Raios e trovões! Então eu disse-lhe: "Sabe, Lacray, leve-me. Para a abordagem de navios inimigos! Hip, hip, hurra! Para a vida e para a morte!'. Mas ele estava ocupado com alguma coisa e não me ouviu.Entãoo "Mossa" estaria inteirinho. Isso eu garanto. Comigo até o diabo...

- Decerto, Comandante-disse Laston, surgindo à porta da cozinha -, tu haverias endireitado as coisas por lá.

-Naturalmente-confirmou Tils. -Nem se discute. Naturalmente.

Depois de mais um cálice, Tils ficou animado, sem intenção, aparentemente, de irse logo, e pôs-se a enumerar todos os encontros, confundindo os próprios pensamentos com o que vira e ouvira em toda a sua longa vida. Não estava bêbado, mas apenas tagarela, e sentia-se um rapaz saudável, disposto a embarcar para o fim do mundo. No entanto, chamara já "senhor Ribeiro" ao cozinheiro, por duas vezes, confundindo-o com o mecânico-chefe do navio "Granel”, e a Laston "Herr Baumann", e, então, o cozinheiro achou que era hora de mandar o Comandante para casa. Para tal havia apenas um meio, mas este era infalível. Laston piscou para o companheiro e disse:

- Bem, Comandante, vamos lá ajudar os nossos rapazes a atracar ao "Pilgrim". ... soltar as amarras e pô-las no "Pilgrim", agora.

Tils encolheu-se e olhou de soslaio para Laston, depois, arrumou nervosamente o colarinho.

- Eu conheço o "Pilgrim”- balbuciou, com uma voz de dar pena. - É um barco muito bom. Em 1914, os recifes abriramlhe duas fendas no casco, perto do Cabo da Fome... à velocidade de doze nós... Naturalmente.

- Isso, vai lá, Tils, vai ajudar os nossos rapazes - , disse o cozinheiro, em tom fingidamente sério.

O Comandante puxou lentamente a pala do quepe, para ajustá-lo bem à cabeça, e, com esforço, levantou-se.

A grossura dos maciços cabos, bem estampada à sua frente, sacudiu da sua cabeça a ebriedade esganiçada de velho; ele perdeu o ânimo e sentiu cansaço.

- É melhor eu ir para casa-disse Tils, a sorrir impetuosamente para Butler e Laston, que estavam sentados diante dele, com ar importante, de braços cruzados e de olhos semicerrados. - Pois, eu devo, conforme prometi, ficar cá até às oito, no mais tardar. Andem lá com essa atracação, rapazes, impilam esta tina para o "Pilgrim”. Háhá! Divirtam-se! Já lá vou eu... 
- Mas que história! - exclamou Butler. - Então já lá vais. Com a breca, Comandante, os rapazes e o mestre voltarão já, dános uma mãozinha!

- Não, não, não! Eu devo, devo ir apressou-se Tils -, porque, compreenda, eu prometi chegar mais cedo, hoje.

- De cá para onde vais? - perguntou o jovem marinheiro Chenk, que entrava.

- Salve, meu rapaz! Foi boa a viagem? A saúde da sua honorável...

- Mãezinha, para que o senhor não se perca - maravilhosamente bem. Mas não vem ao caso. Passe, se puder, pelo Clube Marinho. Ali, como atendente de balcão, trabalha uma moça, Peggy Scotter.

- Peggy Scotter? - resmungou Tils, animando-se e até sem covardia, já, diante dos grossos cabos do "Record". - Como poderia não conhecê-la? Conheço-a, podem dar-me um tiro no coração, eu juro. Pois eu estou a dizer-lhe que a conheço.

- Então, diga-lhe que o seu namorado, Willy Brant, morreu de peste no Eno, há um mês. Acabou de chegar o "Crista de Galo", um marujo seu esteve no "Evrik", onde estavam os nossos, e contou-lhes a notícia. Quem poderia ir? Ninguém. Todos têm medo. Como dizê-lo? Ela erguerá o maior berreiro. Mas o senhor, Tils, pode; é uma pessoa firme e, ainda por cima, velho como as ampulhetas, dará conta da tarefa. Ou não é verdade?

- É verdade - disse Laston em tom categórico, a mover uma perna.

-É verdade-concordou Butler, depois de um instante de mudez.

- Mas veja lá, de uma vez. Não a faça sofrer. Não meta o rabo entre as pernas ensinou Chenk.

-Éisso, sejabreve, que é melhor-fez-lhe coro Butler. - É cortar e jogar para o lado.

De lábios apertados, o velho abaixou a cabeça. Ouvia-se a respiração dos marinheiros, regular, pesada, como no trabalho.

- O caso é que - pôs-se de novo a falar Chenk -, vindo do senhor, isso será, sei lá, como o murmúrio de uma árvore, ou como um relógio tiquetaquear: "Brant mor-reu de pes-te no E-no”. Assim é mais fácil. Eu não irei, sabem, porque isso seria indecente. Para um caso desses eu tenho de beber, e muito.

- Sim. De uma vez! - gritou roucamente Tils e bateu um pé. - Sem hesitação e corajosamente. O coração daquela moça dos diabos é de aço. Um verdadeiro casco de navio! Prometo-lhes, Chenk, e ao senhor, Butler, e ao senhor, Laston. Vou já cuidar do caso.

\section{II}

Peggy Scotter era a chefe dos empregados da cantina localizada no salão inferior do clube, à direita do vestíbulo. Era uma moça airosa, de compleição robusta, sardenta, de nariz arrebitado; os seus olhos cinzentos miravam sérios e interrogantes, e os cabelos ruivos escuros, presos na nuca por uma dúzia de grampos, brilhavam como bronze bem limpo.

Quando a ajudante começara pela décima vez a estudar o forro da manga rendada da sua chefe, Peggy viu Tils. Ele se encaminhou para o balcão, fazendo um semicírculo, parando muitas vezes para cumprimentar polidamente os fregueses, que conhecia.

- Olhe, Mely, chegou o Comandante disse Peggy, a pôr diversos tipos de bolacha em um enorme prato de faiança. - Lá vem ele. Vamos, vamos, move esses pés, velho tagarela!

A cumprimentá-la ainda de longe, Tils abeirou-se e encostou-se ao balcão. Com os olhos, Peggy perguntou-lhe sobre a velhice, os trabalhos do dia e sorriu para o seu rosto solenemente misterioso.

- Boa noite, honorável, florescente, como sempre... - começou Tils, mas entrou a piscar e concluiu: A viagem foi boa, espero... Desculpe, não é isso. Esplêndida noite, suponho. Como vai?

- Quer, Comandante? - disse Peggy, estendendo-lhe um biscoito. - Coma pela saúde de Willy Brant. Há pouco, o senhor perguntou dele. Logo voltará. Foi o que me escreveu há duas semanas. Quando ele chegar, eu porei uma garrafa de um rum maravilhoso naquela mesinha para o senhor... sem chá, eu própria lhe farei companhia, mas, agora, sabe, afaste-se um pouco, porque os atendentes começarão a vir 
com bandejas e alguém acabará por dar-lhe um encontrão.

- Agradeço-lhe - disse Tils, a enfiar lentamente o biscoito em um bolso. - Pois é... Quando o Brant chegar. Peggy! Peggy! - escapou-lhe de repente da garganta.

Mas não conseguiu dizer mais nada, apenas um tremor percorreu-lhe as faces enrugadas. O seu olhar era mádido e confuso.

Peggy admirou-se porque o Comandante nunca se permitira tal familiaridade. Olhava fixamente para ele, chegou até a inclinar-se.

Tils não se decidia a dizer o resto daquele balcão com flores alegres e louça bonita não podia erguer-se o grito ensandecido de uma mulher e ressoar pelo salão inteiro. Ele engoliu nervosamente a partícula de ar, que, expirada por ele, transtornaria o coração de Peggy, com as palavras da verdade sobre o seu Brant-e começou a recuar covardemente, a passinhos miúdos, como um lobacho cambaleante.

Peggy não tornou a conversar com Mely sobre o forro da manga. No seu cérebro, ficara algo estranho das palavras de Tils: “Peggy! Peggy!” Ela pensou em Brant durante uma hora, ficou sombria, qual lâmpada apagada, e, por fim, deu uma punhada no tampo de mármore do balcão.

- Tola, por que permiti que se fosse?! rosnou. - Deixou-me um espinho na alma.

- Será que não percebeu que o Comandante estava embriagadinho? - perguntou Mely. - Estava com bafo, eu senti.

Peggy, então, alegrou-se, mas a partir daquele momento um ponto negro colocouse entre os seus pensamentos e quando, dias depois, a moça recebeu uma missiva da irmã de Tils, esse ponto negro foi-lhe a mola amortecedora do doloroso golpe.-Cheguei, menina - disse Tils, ao chegar, por fim, a casa, à velha mulher sentada em um canto da sala, à máquina de costura. - Estou muito cansado. Tudo está bem, parece, todos estão com saúde. A viagem foi boa. Estive no “Traviata”, no “Stella”, no “Abraham Rapp", no "Record”. Encontrei o capitão Galton. "Boa noite - diz-me o capitão. Salve, diz, Tils, meu bravo! Tu ainda consegues manter as velas viradas para o vento." Convi- dou-me a ir ao teatro. Mas eu fico acanhado, em companhia ruidosa. Bebemos. O capitão deu-me um biscoito, um dólar e isto... Não, eu me confundi, o biscoito eu ganhei da Peggy Scotter. Morreu-lhe o noivo. Encargo desagradável, mas eu me desincumbi dele com bravura. Aíforam... aquelas lágrimas, gritos... Eu pus-me longe dali.

- Não contou nada à Peggy, meu caro disse Rebecca. - Eu o conheço muito bem. Vá deitar-se. Se quiser comer, no armário há uma escudela de almôndegas.

Passou-se um ano. O "Record" tornou ao porto. Mas o Comandante não apareceu morrera de tossir, ao engasgar quando tomava uma sopa. Tils tossiu e sufocou tanto tempo, que na sua débil garganta se rompeu um vaso sangüíneo; o velho ficou fraco, deitouse e, dois dias depois, não se levantou.

- Falta alguma coisa - disse Laston a Butler, com a chegada da noite. - Quem nos contará agora as novidades?

Mal ressoaram as suas palavras e no convés, e em seguida na cozinha, entrou um rapaz descalço, de aspecto medonho, alto, desavergonhado e de cara vermelha.

- Salve! - atroou ele, a agitar o chapéu medonho. - Como navegaram, marinheirinhos? Como foi a viagem? Está viva ainda a família? Ora, vamos! Ofereçam-me um copinho!

- Quem és tu? - perguntou Butler.

- O comandante do porto. Tils bateu as botas, bem... e eu estou no seu lugar.

Laston deu uma risota, levantou-se em silêncio, segurou o rapaz pelo braço e em silêncio levou-o para o cais.

- Adeus! - disse o marinheiro. - Não voltes.

- Mas que coisa estranha! - entrou o rapaz a berrar, quando se viu a distância segura. - Quem perde as botas não compra outras? Pois então, eu queria prestar um serviço a vocês, seus ladrões, seus vigaristas, espertalhões, comida de tubarão!

- Não, não - respondeu-lhe do convés Laston, não ofendido com as palavras do tolo. - A imitação é muito ruim. A tua goela não conseguirá nunca perguntar como se deve se "foi boa a viagem". 